\title{
Analisis Kemampuan Pemahaman Konsep Matematis Mahasiswa Berkemampuan Awal Rendah pada Materi Himpunan
}

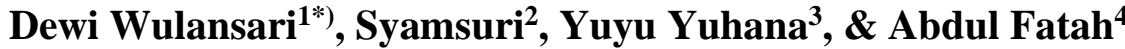 \\ 1,2,3,4 Universitas Sultan Ageng Tirtayasa, Serang, Indonesia
}

\begin{tabular}{l} 
INFO ARTICLES \\
\hline Article History: \\
Received: $09-11-2021$ \\
Revised: $04-12-2021$ \\
Approved: 22-12-2021 \\
Publish Online: $31-12-2021$ \\
\hline
\end{tabular}

Key Words:

Ability; Understand; Mathematical Concepts, Computational; Functional; Set;

\section{(i) (2)}

This article is licensed under a Creative Commons AttributionShareAlike 4.0 International License.

\begin{abstract}
This research is a qualitative descriptive study that aims to analyze the ability of students to understand mathematical concepts in the set material. The research subjects were 13 students of the Mathla'ul Anwar University Mathematics Education Study Program in semester 3, then the subjects were categorized based on the categories of high, medium, and low initial mathematical abilities. Subjects were then selected based on their initial mathematical ability with a low category, to reveal the mathematical understanding ability of students who did not master the material. The instrument is in the form of 2 questions describing the computational and functional comprehension ability tests and interviews. The results showed that students' mathematical understanding abilities on the set material for students who had low initial mathematical abilities were only able to identify the data and information contained in the information given in the questions.
\end{abstract}

\begin{abstract}
Abstrak: Penelitian ini merupakan penelitian deskriptif kualitatif yang bertujuan untuk menganalisis kemampuan pemahaman konsep matematis mahasiswa pada materi himpunan. Subjek penelitian adalah mahasiswa Program Studi Pendidikan Matematika Universitas Mathla'ul Anwar semester 3 sebanyak 13 mahasiswa, kemudian subjek dikategorikan berdasarkan kategori kemampuan awal matematis tinggi, sedang, dan rendah. Subjek kemudian dipilih berdasarkan kemampuan awal matematis dengan kategori rendah, untuk mengungkap kemampuan pemahaman matematis mahasiswa yang kurang menguasai materi tersebut. Instrumen berupa 2 soal uraian tes kemampuan pemahaman komputasional dan fungsional serta wawancara. Hasil penelitian menunjukkan bahwa kemampuan pemahaman matematis mahasiswa pada materi himpunan bagi mahasiswa yang memiliki kemampuan awal matematis kategori rendah, hanya mampu mengidentifikasi data dan informasi yang terdapat dalam informasi yang diberikan pada soal.
\end{abstract}

Correspondence Address: Jl. Raya Jakarta KM 4 Pakupatan, Serang, Banten, Indonesia; e-mail: dewiewulansari28@gmail.com

How to Cite (APA $6^{\text {th }}$ Style): Wulansari, dkk. (2021). Analisis Kemampuan Pemahaman Konsep Matematis Mahasiswa Berkemampuan Awal Rendah pada Materi Himpunan. JKPM (Jurnal Kajian Pendidikan Matematika), 7(1): 71-84. http://dx.doi.org/10.30998/jkpm.v7i1.11328

Copyright: 2021 Dewi Wulansari, Syamsuri Syamsuri, Yuyu Yuhana, Abdul Fatah

Competing Interests Disclosures: The authors declare that they have no significant competing financial, professional or personal interests that might have influenced the performance or presentation of the work described in this manuscript. 


\section{PENDAHULUAN}

Matematika adalah salah satu mata pelajaran yang dipelajari di sekolah dan memegang peranan yang sangat penting di dalam kehidupan manusia. Di zaman modern dan terus berkembang seperti sekarang ini, manusia tidak dapat dilepaskan dari peran matematika. Matematika juga merupakan salah satu mata pelajaran pokok yang telah diajarkan sejak usia dini dan diaplikasikan dengan secara nyata dalam kehidupan sehari-hari. Kebutuhan manusia terhadap matematika dapat dilihat dari banyaknya kegiatan yang melibatkan perhitungan dan angka-angka. Seperti yang dikatakan oleh Aulia, et.al (2017) bahwa matematika merupakan salah satu cabang ilmu pengetahuan yang mempunyai peranan yang penting dalam kehidupan manusia. Meskipun begitu, matematika masih sering kali dianggap sebagai mata pelajaran yang paling rumit dan tidak disenangi. Seperti yang diungkapkan oleh Rosita, et. al. (2021) bahwasanya matematika sangat tidak disukai siswa karena dipandang sebagai mata pelajaran yang rumit. Selain itu, menurut Suparni, et. al. (2021) yang menjadi penyebab matematika selalu dihindari adalah karena ilmunya yang bersifat abstrak.

Pemahaman konsep seperti yang diungkapkan Yanti, et. al. (2019) merupakan kecakapan yang paling dasar dalam matematika. Ferdiana \& Mulyatna (2020) memberikan penegasan juga bahwa pemahaman konsep merupakan kemampuan dasar yang dimiliki oleh seseorang dalam pembelajaran matematika. Menurut Jafar (2013), pemahaman konsep adalah hasil dari aktivitas berpikir seseorang dalam memahami konsep yang dimaksud. Pemahaman dapat didefinisikan sebagai kemampuan dalam menangkap makna dari suatu konsep dan diartikan juga sebagai kesanggupan untuk menyatakan suatu definisi dengan perkataan sendiri. Merujuk kepada Davita et. al. 2020), seseorang disebut paham jika seseorang tersebut sanggup menggambarkan sesuatu hal yang berbeda dengan yang terdapat di dalam buku, dan dapat menggunakan bahasanya sendiri. Di sisi lain, Suarsana, et. al. (2018) menyatakan kemampuan siswa dalam memahami suatu konsep membuat siswa tersebut dapat mengaitkan materi yang telah diajarkan dengan materi baru, dan membuat siswa membangun struktur kognitifnya secara optimal. Kemudian Fajar, et. al. (2018) memberikan penekanan bahwa pemahaman konsep merupakan unsur yang penting dalam pembelajaran matematika. Penguasaan banyak konsep, memungkinkan terjadinya proses pemecahan masalah dengan lebih baik, karena dalam memecahkan masalah diperlukan aturan-aturan, dan aturan-aturan tersebut didasarkan pada konsep-konsep yang dimiliki. Berdasarkan pendapat tersebut, dapat diambil kesimpulan bahwa pemahaman konsep dalam matematika adalah kemampuan untuk menerapkan konsep, prosedur, dan aktivitas berpikir dalam menghubungkan suatu materi dengan situasi yang lain.

Menurut Sumarmo (2010), pemahaman matematis menurut Pollatsek terdiri dari (1) Pemahaman komputasional, yaitu pemahaman di mana seseorang dapat memakai rumus atau cara matematika dalam perhitungan sederhana, dan melakukan perhitungan secara algoritmik; (2) Pemahaman fungsional, yaitu pemahaman di mana seseorang dapat mengaitkan satu konsep/prinsip lainnya, dan menyadari proses yang dikerjakannya. Kedua jenis pemahaman matematis ini tentunya sangat banyak diperlukan dalam mempelajari materi matematika lanjut, khususnya di perguruan tinggi.

Materi pembelajaran matematika lebih rumit untuk dipelajari pada jenjang perguruan tinggi dikarenakan materi yang disajikan lebih bersifat abstrak, misalnya pada materi himpunan yang dipelajari di mata kuliah dasar-dasar matematika Jenjang Strata 1 Program Studi Pendidikan Matematika di salah satu PTS di Pandeglang. Menurut Hidayat \& Pujiastuti (2019), belajar materi himpunan meliputi belajar konsep, tidak terdapat banyak rumus dalam materi ini, akan tetapi dalam materi ini digunakan berbagai macam simbol, notasi, dan diagram. Jika seseorang belajar himpunan, maka seseorang tersebut membutuhkan pemahaman konsep yang baik. Seperti yang dikatakan oleh Farhan \& Zulkarnain (2019) bahwa salah satu tujuan dalam pembelajaran matematika adalah siswa dapat memahami konsep, menjelaskan keterkaitan antara konsep dan dapat memecahkan masalah matematis pada level kesulitan tertentu secara baik dan benar. 
Pada saat ini, kemampuan pemahaman konsep matematis siswa masih tergolong rendah. Dini, et. al. (2018) mengungkapkan seperti yang terjadi di sekolah, penguasaan matematika pada siswa masih tergolong rendah, pemahaman matematis siswa dalam belajar matematika masih kurang dan self confidence siswa sangat rendah, sehingga hasil dari pembelajarannya kurang bermakna. Sejalan dengan hasil penelitian yang telah dilakukan oleh Ayuningrum, et.al. menemukan bahwa penyebab kesulitan belajar siswa yaitu kurangnya memahami konsep. Hasil penelitian lainnya dari Asih \& Imami (2021) menyatakan bahwa siswa memiliki kemampuan pemahaman konsep matematis yang masih tergolong rendah pada materi himpunan.

Pada penelitian sebelumnya yang dilakukan oleh Agustina, et.al. (2021) menunjukkan bahwa secara keseluruhan mahasiswa pendidikan matematika masih kesulitan dalam menyelesaikan soal pemahaman konsep matematis terutama pada indikator pemahaman fungsional. Selanjutnya pada penelitian kali ini, yang membedakan dari penelitian sebelumnya adalah subjek yang dianalisis akan dikategorikan terlebih dahulu berdasarkan kemampuan awal matematisnya, lalu subjek akan dianalisis berdasarkan kategori kemampuan awal matematis rendah. Penelitian ini ditujukan kepada mahasiswa untuk mengetahui bagaimana pemahamannya pada materi himpunan. Peneliti berharap dengan diadakannya penelitian ini akan sangat bermanfaat untuk penelitian selanjutnya, terutama bagi para peneliti yang akan melakukan penelitian mengenai kemampuan pemahaman konsep matematis. Berdasarkan pemaparan yang sudah diuraikan tersebut, peneliti tertarik untuk melakukan penelitian dengan judul “Analisis Kemampuan Pemahaman Konsep Matematis Mahasiswa Berkemampuan Awal Rendah pada Materi Himpunan.”

\section{METODE}

Metode yang digunakan dalam penelitian ini adalah kualitatif deskriptif untuk mengungkapkan kemampuan pemahaman matematis mahasiswa Universitas Mathla'ul Anwar yang telah mempelajari materi himpunan di mata kuliah dasar-dasar matematika. Penelitian ini dilakukan di Universitas Mathla'ul Anwar Kabupaten Pandeglang, Banten.

Subjek penelitian diambil dari mahasiswa Program Studi Pendidikan Matematika Universitas Mathla'ul Anwar semester tiga di 1 kelas yang terdiri dari 13 mahasiswa. Subjek ini ditentukan karena mahasiswa semester 3 tersebut telah mempelajari materi himpunan di mata kuliah dasar-dasar matematika pada saat semester 1. Pemilihan subjek juga ditentukan berdasarkan hasil wawancara dengan salah satu dosen pengajar yang memberikan pernyataan bahwa mahasiswa tersebut mempunyai kemampuan pemahaman matematis yang beragam. Studi pendahuluan dilakukan peneliti terhadap 13 mahasiswa dengan menggunakan soal tes kemampuan awal matematis. Dari hasil studi pendahuluan tersebut akan menunjukkan kategori kemampuan awal matematis mahasiswa tersebut. Kategori tersebut terdiri dari kemampuan awal matematis tinggi, sedang, dan rendah serta pada penelitian ini hanya diambil pada kategori rendah. Hasil kategori tersebut diambil berdasarkan dari perhitungan dengan mengacu pada Tabel 1 ..

\section{Tabel 1. Kategori Kemampuan Awal Matematis}

\begin{tabular}{cccc}
\hline & Tinggi & Sedang & Rendah \\
\cline { 2 - 4 } Kemampuan & $x \geq(\bar{x}+S D)$ & $(\bar{x}-S D)<x<(\bar{x}+S D)$ & $x \leq(\bar{x}-S D)$ \\
Awal Matematis & $x \geq 12,25$ & $7,69<x<12,25$ & $x \leq 7,69$
\end{tabular}

Sumber: Melawati (2020)

Peneliti memberikan instrumen kemampuan awal matematis kepada 13 mahasiswa semester 3, kemudian penetapan subjek penelitian dipilih berdasarkan hasil tes kemampuan awal matematis dengan kategori rendah, untuk mengungkap kemampuan pemahaman matematis mahasiswa yang kurang menguasai 
materi tersebut. Subjek terpilih tersebut kemudian dilakukan wawancara sebagai alat triangulasi jawaban yang ditulis oleh subjek penelitian untuk mempelajari dan menelusuri kemampuan pemahaman matematis subjek dalam menyelesaikan soal yang diberikan.

Instrumen berupa soal tes kemampuan pemahaman konsep matematis, wawancara, dan peneliti sendiri sebagai instrumen kunci. Soal tes kemampuan pemahaman konsep matematis terdiri dari soal uraian sebanyak 2 soal, yang diadopsi dari penelitian Agustina, et. al. (2021) dan sudah dinyatakan layak digunakan untuk penelitian. Data dikumpulkan menggunakan metode tes tertulis dan wawancara yang dilakukan secara online dengan menggunakan aplikasi Google Meet. Metode pengumpulan data ini dilakukan oleh peneliti dengan tujuan untuk mendapatkan data yang jenuh, dengan membandingkan data yang diperoleh dari setiap metode pengumpulan data. Data tes tertulis diperoleh dari hasil pekerjaan subjek pada tes kemampuan awal matematis. Peneliti merekam aktivitas saat subjek mengerjakan tes dengan tujuan sebagai bukti data penelitian. Setelah subjek menyelesaikan tes, peneliti mengkategorikan kemampuan awal matematis subjek, dan peneliti melakukan wawancara dengan subjek dengan kategori kemampuan awal matematis rendah dengan tujuan untuk mendapatkan data secara mendalam. Peneliti melakukan perekaman aktivitas Google Meet yang merupakan bukti penelitian dan data wawancara. Setiap subjek melaksanakan tes dan wawancara pada waktu yang tidak bersamaan melainkan pada waktu yang berbeda agar peneliti bisa fokus dalam mengamati setiap subjeknya. Data yang sudah diambil kemudian dilakukan penganalisisan menggunakan model yang dikemukakan oleh Miles \& Huberman (1994) dengan cara mereduksi data, penyajian data, dan penarikan kesimpulan. Pada tahapan reduksi, data yang terkumpul akan diubah kedalam bentuk transkrip, yaitu: transkrip hasil pekerjaan subjek dan transkrip wawancara. Kemudian data-data yang sudah berupa transkrip tersebut akan dipilah, dicari pola yang tetap, dan difokuskan pada kemampuan pemahaman matematis menggunakan indikator kemampuan pemahaman matematis menurut Sumarmo dalam Agustina, et. al. (2021), seperti yang ditampilkan dalam Tabel 2 .

Tabel 2. Indikator Tes Kemampuan Pemahaman Konsep Matematis

\begin{tabular}{clll}
\hline No. & Pemahaman Matematis & \multicolumn{2}{c}{ Indikator } \\
\hline 1. $\begin{array}{l}\text { Pemahaman } \\
\text { Komputasional }\end{array}$ & 1.1 & $\begin{array}{l}\text { Mengidentifikasi data/konsep/prinsip yang terdapat } \\
\text { dalam informasi yang diberikan. } \\
\text { Melakukan perhitungan terhadap proses matematika } \\
\text { dengan menyertakan aturan/prinsip/konsep yang } \\
\text { digunakan pada setiap langkah pengerjaan. }\end{array}$ \\
\hline 2. Pemahaman Fungsional & 2.1 & $\begin{array}{l}\text { Mengenali data/konsep/prinsip yang termuat dalam } \\
\text { informasi yang diberikan. } \\
\text { Mengaitkan antara satu konsep/prinsip dengan } \\
\text { konsep/prinsip yang lainnya dan serta } \\
\text { menyatakannya dalam simbol matematika. } \\
\text { Menentukan solusi akhir beserta alasannya }\end{array}$ \\
& 2.2 &
\end{tabular}

Sumber: Sumarmo dalam Agustina, et. al. (2021)

Bentuk soal uraian tes kemampuan pemahaman matematis yang mengungkap indikator pemahaman komputasional dan fungsional pada materi himpunan seperti yang disajikan dalam Tabel $3 .$. 


\section{Tabel 3. Instrumen Tes Kemampuan Pemahaman Matematis}

\begin{tabular}{|c|c|c|}
\hline No. Soal & Indikator & Isi Soal \\
\hline 1. & $\begin{array}{l}\text { Kemampuan } \\
\text { pemahaman } \\
\text { komputasional }\end{array}$ & $\begin{array}{l}31 \text { mahasiswa kelas X1C di mana terdapat } 15 \\
\text { mahasiswa yang mengikuti kompetisi matematika, } 13 \\
\text { mahasiswa yang mengikuti kompetisi IPA, dan } \\
\text { sisanya ada } 7 \text { mahasiswa tidak mengikuti kompetisi } \\
\text { apapun. Tentukan banyak mahasiswa yang mengikuti } \\
\text { kedua kompetisi tersebut! }\end{array}$ \\
\hline 2. & $\begin{array}{l}\text { Kemampuan } \\
\text { pemahaman } \\
\text { fungsional }\end{array}$ & $\begin{array}{l}\text { Diketahui: } \\
K=\{x \mid 2<x<8, x \in \text { bilangan asli }\} \text {. } \\
L=\{x \mid x=5 \text { bilangan prima pertama }\} \text {. } \\
\text { Apakah ada hasil dari }(K \cap L), \cup K \text { ? Jika ada, } \\
\text { tentukan hasilnya! }\end{array}$ \\
\hline
\end{tabular}

Sumber: instrumen penelitian, 2021

Setelah melalui tahapan reduksi, data akan disajikan. Dalam penelitian ini, data yang diperoleh berupa kalimat-kalimat yang berkaitan dengan fokus penelitian, sehingga sajian data terdiri dari sekumpulan informasi yang tersusun secara sistematis dan dapat ditarik kesimpulan. Tahapan akhir pada analisis data yaitu penarikan kesimpulan. Penarikan kesimpulan tersebut berisi tentang deskripsi kemampuan pemahaman matematis subjek dalam materi himpunan. Adapun uji keabsahan data hasil penelitian dengan memakai triangulasi waktu (dengan dua periode waktu yang berbeda) dan triangulasi teknik (memberikan analisis hasil tes tertulis, dan wawancara).

\section{HASIL}

Berdasarkan hasil tes kemampuan awal matematis dari 13 mahasiswa diperoleh bahwa 1 orang mahasiswa masuk ke dalam kategori tinggi, 10 orang mahasiswa masuk kedalam kategori sedang, dan 2 orang mahasiswa masuk kedalam kategori rendah. Berikutnya adalah pemilihan subjek terpilih didasarkan pada kategori kemampuan awal matematis rendah dengan rincian subjek seperti dalam Tabel 4.

Tabel 4. Pengambilan Subjek Penelitian

\begin{tabular}{cccc}
\hline No. & Inisial Mahasiswa & Skor Kemampuan Awal Matematis & Kode Subjek \\
\hline 1. & M & 5 & S1 \\
2. & F & 7 & S2
\end{tabular}

Sumber: diolah dari data penelitian, 2021

Setelah memperoleh Subjek penelitian berdasarkan tes kemampuan awal matematis rendah, langkah selanjutnya adalah wawancara untuk menggali secara mendalam informasi mengenai kemampuan pemahaman matematis subjek pada setiap indikator soal. Hasil penelitian kemudian diuraikan berdasarkan penyajian mengenai proses kemampuan pemahaman matematis tiap subjek dalam menjawab tiap indikator soal.

Subjek S1 dalam menjawab soal no. 1 dengan indikator kemampuan pemahaman komputasional terlihat dalam Gambar 1.. 


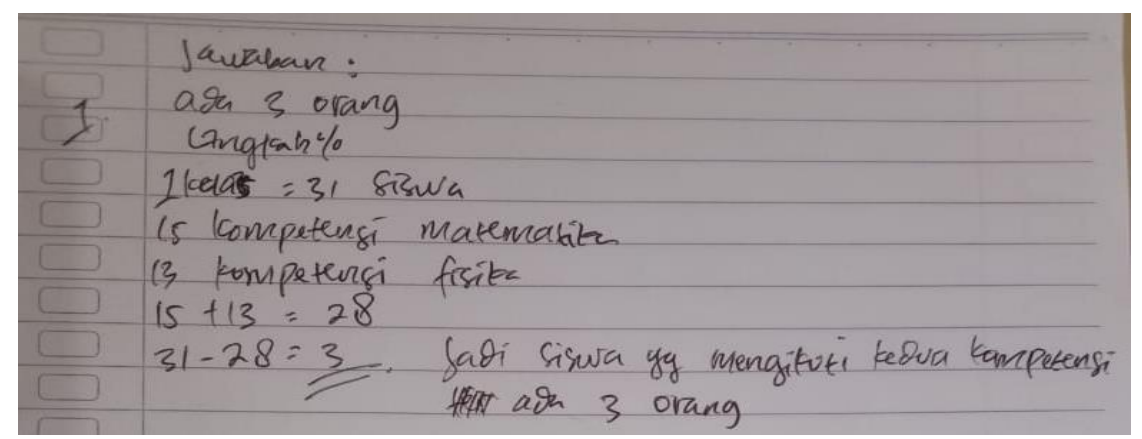

Gambar 1. Jawaban Nomor 1 Subjek 1

Berdasarkan jawaban Subjek 1 dari soal no. 1, indikator kemampuan pemahaman komputasional kemudian diperinci lagi. Tinjauan awal terkait indikator mengidentifikasi data/konsep/prinsip yang terdapat dalam informasi yang diberikan. Dapat dideskripsikan dari jawaban Subjek 1 (lihat Gambar 1.), tentang kemampuan mengidentifikasi data/konsep/prinsip yang terdapat dalam informasi yang diberikan, menunjukkan bahwa Subjek S1 mampu mengidentifikasi hal-hal yang terdapat dari soal yaitu tentang jumlah keseluruhan siswa dalam satu kelas, jumlah siswa yang mengikuti kompetisi matematika, dan jumlah siswa yang mengikuti kompetisi IPA. Subjek juga dapat mengidentifikasi hal yang ditanyakan pada soal. Meskipun masih ada kekeliruan dalam penulisan kompetisi IPA menjadi fisika dan masih ada kekurangan penulisan informasi yang disajikan di soal yaitu jumlah siswa yang tidak mengikuti kedua kompetisi tersebut. Deskripsi awal berdasarkan hasil jawaban tertutlis, kemudian ditindaklanjyti dengan wawancara kepada Subjek 1. Sehingga, hal ini juga diperkuat pada jawaban wawancara Subjek S1 sebagai berikut.

"Ada jumlah keseluruhan mahasiswa kelas X1C yaitu 31 orang, 15 orang mengikuti kompetisi matematika, 13 orang mengikuti kompetisi fisika, dan ada 7 orang tidak mengikuti keduanya. Lalu yang ditanyakan di soal adalah jumlah yang mengikuti kedua kompetisi tersebut."

Berdasarkan hasil wawancara Subjek S1 disebutkan bahwa Subjek S1 dapat mengidentifikasi hal-hal yang disajikan di soal. Meskipun di foto jawaban tidak lengkap dituliskan, akan tetapi pada saat wawancara Subjek S1 dapat menyebutkan dengan lengkap hal-hal yang terdapat dalam informasi yang diberikan. Subjek $\mathrm{S} 1$ juga menyebutkan hal yang ditanyakan dalam soal secara tertulis maupun secara lisan. Dari paparan di atas dapat disimpulkan bahwa subjek S1 mampu mengidentifikasi data/konsep/prinsip yang terdapat dalam informasi yang diberikan dan memenuhi indikator 1 dari kemampuan pemahaman komputasional.

Kemampuan pemahaman komputasional kemudian dideskripsikan lagi berdasarkan indikator melakukan perhitungan terhadap proses matematika dengan menyertakan aturan/prinsip/konsep yang digunakan pada setiap langkah pengerjaan. Deskripsi jawaban Subjek S1 pada Gambar 1. tentang kemampuan melakukan perhitungan terhadap proses matematika dengan menyertakan aturan/prinsip/konsep yang digunakan pada setiap langkah pengerjaan, menunjukkan bahwa Subjek S1 menuliskan informasi yang diketahui dan ditanyakan dari soal. Informasi tersebut oleh Subjek S1 disajikan ulang berupa hitungan dengan menyertakan aturan/prinsip/konsep yang keliru dari jawaban sebenarnya. Subjek S1 langsung menjumlahkan kedua hal yang diketahui di soal tanpa menyertakan aturan/prinsip/konsep yang seharusnya. Berikut jawaban hasil wawancara Subjek S1 tersebut.

"Pertama saya tuliskan diketahuinya dulu, lalu ada 15 orang yang mengikuti kompetisi matematika, 13 orang yang mengikuti kompetisi fisika, lalu tinggal ditambahkan 15 yang mengikuti kompetisi matematika dengan 13 yang mengikuti kompetisi fisika, hasilnya 28. Lalu yang ditanyakan berapa orang yang mengikuti kedua kompetisi tersebut, berarti tinggal dikurangkan saja jumlah seluruh mahasiswa dikurangi jumlah yang mengikuti kedua kompetisi tersebut $31-28=3$ orang." 
Subjek S1 keliru dalam melakukan perhitungan tersebut, karena langsung menjumlahkan mahasiswa yang mengikuti kompetisi matematika dengan kompetisi IPA. Selain itu, pada hasil wawancara Subjek S1 juga menyadari bahwa seharusnya menggambar diagram venn himpunan terlebih dahulu agar dapat mempermudah perhitungan pada setiap langkah pengerjaan. Berdasarkan analisis dan wawancara di atas, dapat diambil kesimpulan bahwa Subjek S1 belum mampu melakukan perhitungan terhadap proses matematika dengan menyertakan aturan/prinsip/konsep yang digunakan pada setiap langkah pengerjaan dan belum memenuhi indikator 2 dari kemampuan pemahaman komputasional.

Selanjutnya pada Gambar 2. diberikan hasil jawaban tertulis Subjek S1 dari soal no. 2 dengan indikator kemampuan pemahaman fungsional.

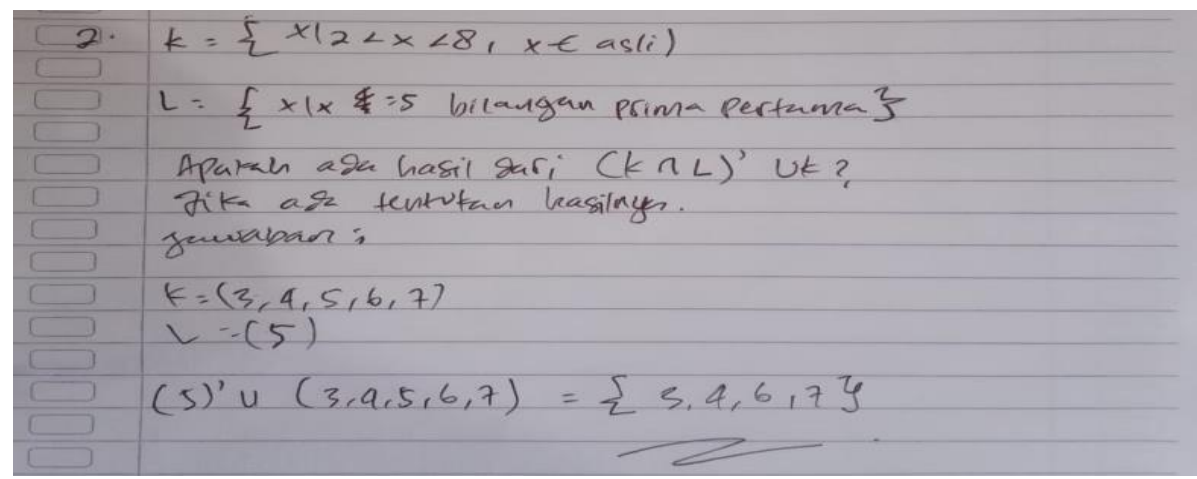

Gambar 2. Jawaban Nomor 2 Subjek 1

Kemampuan pemahaman fungsional sendiri lebih lanjut dapat dijelaskan berdasarkan indikator mengenali data/konsep/prinsip yang termuat dalam informasi yang diberikan, indikator mengaitkan antara satu konsep/prinsip dengan konsep/prinsip yang lainnya dan serta menyatakannya dalam simbol matematika dan juga indikator menentukan solusi akhir beserta alasannya (dapat dilihat kembali di Tabel 2.).

Pada indikator mengenali data/konsep/prinsip yang termuat dalam informasi yang diberikan, berdasarkan deskripsi pada jawaban Subjek S1 pada Gambar 2., terlihat bahwa subjek berusaha mengenali data/konsep/prinsip yang termuat dalam informasi yang diberikan, akan tetapi ada salah menafsirkan data/konsep/prinsip yang disebutkan pada soal. Subjek S1 keliru dalam menuliskan anggota himpunan L yang hanya dituliskan satu anggota yaitu 5. Berdasarkan hasil wawancara, Subjek S1 menjelaskan bahwa dia keliru dalam menafsirkan maksud dari informasi yang disajikan di soal. Berikut hasil wawancara dengan Subjek S1 tersebut.

"Kalau K itu anggota himpunannya 3, 4, 5, 6, dan 7 tetapi L hanya 5 saja anggotanya."

Tetapi ketika peneliti meminta Subjek S1 untuk menyebutkan 5 bilangan prima pertama, dalam hasil wawancara Subjek S1 dapat menyebutkan keseluruhan anggota himpunannya. Berikut wawancara dengan Subjek S1 tersebut.

"5 anggota bilangan prima pertama yaitu 2, 3, 5, 7, dan $11 . "$

Berdasarkan hasil wawancara tersebut, maka dapat diketahui bahwa Subjek S1 sudah mengenali data/konsep/prinsip yang termuat dalam informasi yang diberikan. Meskipun pada gambar jawaban Subjek S1 keliru dalam menuliskan anggota himpunan L, tetapi Subjek S1 dapat menyebutkannya dalam wawancara dengan peneliti. Oleh karena itu, peneliti menyimpulkan bahwa Subjek S1 mampu mengenali data/konsep/prinsip yang termuat dalam informasi yang diberikan dan memenuhi indikator 1 dari kemampuan pemahaman fungsional.

Sedangkan kemampuan pemahaman fungsional pada indikator mengaitkan antara satu konsep/prinsip dengan konsep/prinsip yang lainnya dan serta menyatakannya dalam simbol matematika, berdasarkan 
deskripsi pada jawaban Subjek S1 pada Gambar 2., terlihat bahwa Subjek S1 belum dapat mengaitkan antara satu konsep/prinsip dengan konsep/prinsip yang lainnya dan serta menyatakannya dalam simbol matematika. Subjek S1 keliru dalam menafsirkan hal yang ditanyakan dalam soal, Subjek S1 tidak mengetahui maksud dari tanda kutip yang merupakan komplemen. Subjek S1 juga keliru dalam menafsirkan simbol irisan dan gabungan. Hal tersebut dapat terlihat dari jawaban Subjek S1 yang keliru dan tidak mengaitkan satu per satu konsepnya. Subjek langsung memberikan jawaban tanpa menuliskan konsep dan keterkaitannya terlebih dahulu. Berikut jawaban wawancara dengan Subjek S1.

"Saya lupa Bu dengan maksud tanda kutip itu, tapi pertama-tama yang saya kerjakan yaitu dengan menuliskan anggota himpunannya terlebih dahulu, $L$-nya kan 5 , K nya itu 3, 4, 5, 6, dan

7. Jadi saya masukan saja 5 ' $U\{3,4,5,6,7\}$ dan hasilnya $\{3,4,6$, dan 7$\} . "$

Berdasarkan hasil wawancara tersebut, maka dapat diketahui bahwa Subjek S1 keliru dalam menafsirkan tanda komplemen, keliru dalam menafsirkan simbol irisan dan gabungan, serta tidak dapat mengaitkan antara satu konsep/prinsip dengan yang lainnya. Maka dapat disimpulkan bahwa subjek S1 belum mampu mengaitkan antara satu konsep/prinsip dengan konsep/prinsip yang lainnya dan serta menyatakannya dalam simbol matematika, dan belum memenuhi indikator 2 dari kemampuan pemahaman fungsional.

Indikator selanjutnya dari kemampuan pemahaman fungsional adalah menentukan solusi akhir beserta alasannya. Berdasarkan deskripsi pada jawaban Subjek S1 pada Gambar 2., Subjek S1 keliru dalam menentukan solusi akhir beserta alasannya, dikarenakan Subjek S1 keliru dalam menafsirkan tanda komplemen, keliru dalam menafsirkan simbol irisan dan gabungan, serta tidak dapat mengaitkan antara satu konsep/prinsip dengan yang lainnya. Berikut hasil wawancara dengan Subjek S1.

"Saya salah menafsirkan lambang irisan, gabungan, dan komplemen, jadi solusi akhir saya

himpunannya $\{3,4,6$, dan 7$\} . "$

Berdasarkan hasil wawancara tersebut, maka dapat diketahui bahwa Subjek S1 keliru dalam menentukan solusi akhir beserta alasannya. Maka dapat disimpulkan bahwa Subjek S1 belum mampu menentukan solusi akhir beserta alasannya, dan belum memenuhi indikator 3 dari kemampuan pemahaman fungsional. Subjek S1 mengatakan bahwa soal pemahaman fungsional ini lebih sulit dari pada soal pemahaman komputasional.

Penyajian hasil penelitian berdasarkan data yang diperoleh pada Subjek S2 pun sama halnya seperti penyajian data yang diperoleh dari Subjek S1. Data disajikan untuk tiap nomor pada masing-masing kemampuan pemahaman komputasional (pemberian instrumen tes soal no.1) dan kemampuan pemahaman fungsional (pemberian instrumen tes soal no.2)

Deskripsi data dimulai berdasarkan hasil jawaban Subjek S2 pada soal no. 1 untuk melihat kemampuan pemahaman komputasional, disajikan dalam Gambar 3..

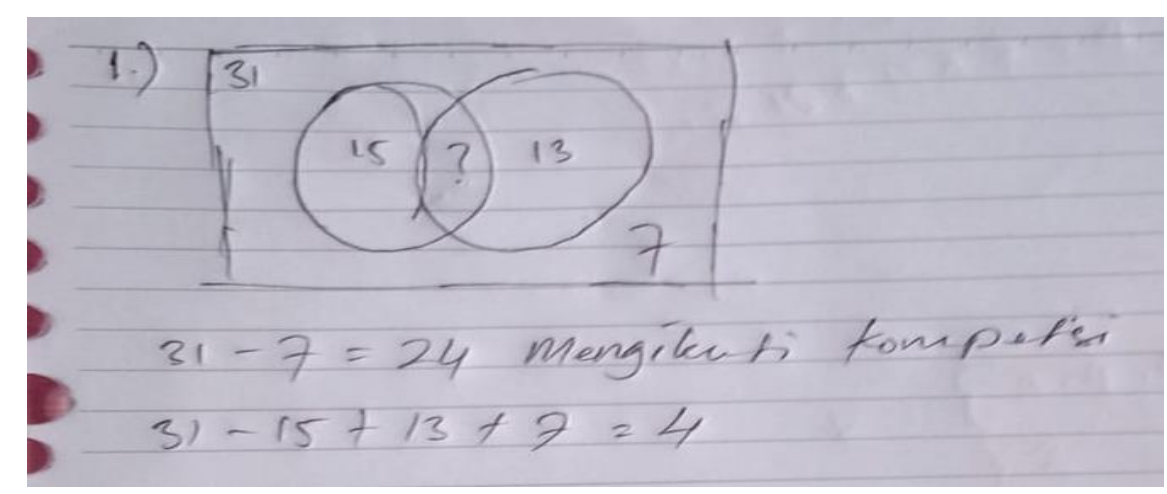

Gambar 3. Jawaban Nomor 1 Subjek 2 
Selanjutnya hasil penelitian untuk Subjek S2 diuraikan berdasarkan indikator pertama dari kemampuan komputasional yaitu mengidentifikasi data/konsep/prinsip yang terdapat dalam informasi yang diberikan. Berdasarkan deskripsi pada jawaban Gambar 3. tentang kemampuan mengidentifikasi data/konsep/prinsip yang terdapat dalam informasi yang diberikan, Subjek S2 mampu mengidentifikasi halhal yang terdapat dari soal yaitu tentang jumlah keseluruhan siswa dalam satu kelas, jumlah siswa yang mengikuti kompetisi matematika, dan jumlah siswa yang mengikuti kompetisi IPA. Subjek S2 menggambar diagram venn untuk mempermudah mengidentifikasi kelompok himpunan yang diketahui pada soal, meskipun masih ada kekurangan dalam penulisannya yaitu tidak adanya keterangan yang dipakai dalam diagram venn tersebut. Subjek S2 mengetahui apa maksud dari pertanyaan pada soal. Hal ini juga diperkuat pada jawaban wawancara Subjek S2 sebagai berikut.

"Yang diketahui di soal itu jumlah keseluruhan mahasiswa kelas X1C berjumlah 31 orang, di mana 15 orang mengikuti kompetisi matematika dan 13 orang mengikuti kompetisi IPA, dan 7 orang itu tidak mengikuti kompetisi apapun, itu yang diketahuinya dulu Bu. Lalu yang ditanyakan adalah yang mengikuti kedua kompetisi tersebut ada berapa orang."

Berdasarkan hasil wawancara tersebut, Subjek S2 dapat mengidentifikasi hal-hal yang disajikan di soal. Subjek S2 mengetahui informasi yang diberikan pada soal dan menuangkannya dalam diagram venn, meskipun di foto jawaban tidak lengkap dituliskan, akan tetapi pada saat wawancara Subjek S2 dapat menyebutkan dengan lengkap hal-hal yang terdapat dalam informasi yang diberikan. Subjek S2 juga mengatakan hal yang ditanyakan dalam soal secara tertulis maupun secara lisan. Dari paparan di atas dapat diambil kesimpulan bahwa subjek S2 mampu mengidentifikasi data/konsep/prinsip yang terdapat dalam informasi yang diberikan dan memenuhi indikator 1 dari kemampuan pemahaman komputasional.

Indikator selanjutnya dari kemampuan komputasional adalah melakukan perhitungan terhadap proses matematika dengan menyertakan aturan/prinsip/konsep yang digunakan pada setiap langkah pengerjaan. Deskripsi jawaban Subjek S2 pada Gambar 3. tentang kemampuan melakukan perhitungan terhadap proses matematika dengan menyertakan aturan/prinsip/konsep yang digunakan pada setiap langkah pengerjaan, Subjek S2 menuliskan kembali informasi yang diketahui dan ditanyakan dari soal. Informasi tersebut oleh Subjek S2 disajikan ulang berupa gambar diagram venn, pada tahap pengerjaan selanjutnya Subjek S2 mengurangi jumlah keseluruhan mahasiswa dengan jumlah mahasiswa yang tidak mengikuti kompetisi apapun untuk menemukan jumlah mahasiswa yang mengikuti kompetisi tersebut. Di tahap selanjutnya Subjek S2 keliru dalam menempatkan operasi penjumlahan dan pengurangan untuk mendapatkan jawaban yang ditanyakan yaitu jumlah mahasiswa yang mengikuti kompetisi keduanya. Tetapi pada saat wawancara Subjek S2 menyadari kekeliruannya dan menjelaskan posisi operasi penjumlahan dan pengurangan yang seharusnya. Berikut jawaban hasil wawancara Subjek S2 tersebut.

"Pertama saya gambarkan diagram venn-nya terlebih dahulu, lalu dipisahkan 15 orang yang mengikuti kompetisi matematika, dan 13 orang yang mengikuti kompetisi IPA, selanjutnya saya mengurangkan jumlah keseluruhan mahasiswa dengan jumlah mahasiswa yang tidak mengikuti kompetisi apapun, dapet tuh Bu jumlah mahasiswa yang mengikuti kompetisi, lalu saya mengurangkan dan menjumlahkan jumlah keseluruhan mahasiswa dengan mahasiswa yang mengikuti kompetisi matematika dan IPA juga yang tidak mengikuti keduanya sehingga didapat nilai 4. Tapi sepertinya saya salah menempatkan angka 31-nya Bu, dan tanda - itu seharusnya di akhir, jadi seharusnya $15+13+7-31=4 . "$

Subjek S2 keliru dalam melakukan perhitungan tersebut, karena tidak menyertakan aturan/prinsip/konsep yang digunakan pada setiap langkah pengerjaan, meskipun hasil akhirnya benar, tetapi Subjek S2 belum tepat dalam memberikan alasan dari jawabannya tersebut. Berdasarkan analisis dan wawancara di atas, dapat diambil kesimpulan bahwa Subjek S2 belum mampu melakukan perhitungan 
terhadap proses matematika dengan menyertakan aturan/prinsip/konsep yang digunakan pada setiap langkah pengerjaan dan belum memenuhi indikator 2 dari kemampuan pemahaman komputasional.

Uraian selanjutnya dipaparkan hasil pengerjaan untuk mengukur kemampuan pemahaman fungsional (soal no.2), terlihat dalam Gambar 4.

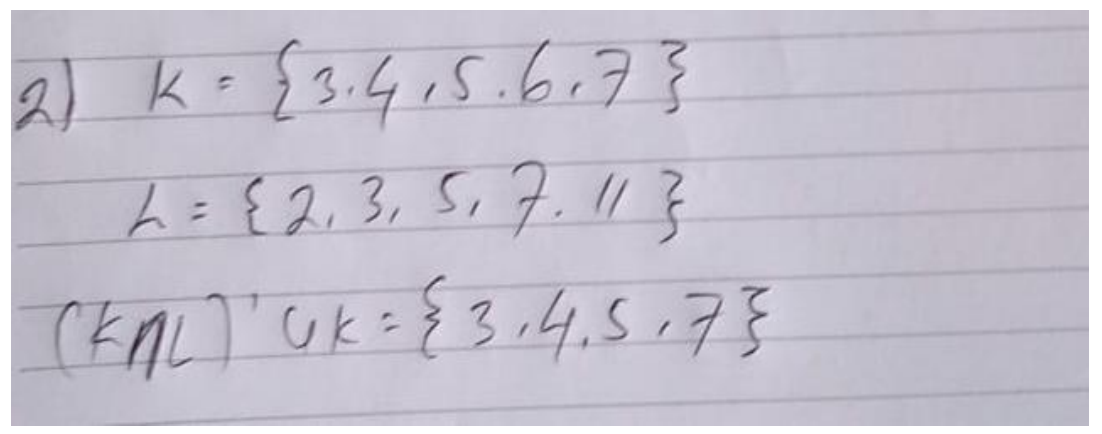

Gambar 4. Jawaban Nomor 2 Subjek 2

Mengacu pada Tabel 2. kemampuan pemahaman fungsional diuraikan berdasarkan indikator mengenali data/konsep/prinsip yang termuat dalam informasi yang diberikan, indikator mengaitkan antara satu konsep/prinsip dengan konsep/prinsip yang lainnya dan serta menyatakannya dalam simbol matematika dan indikator menentukan solusi akhir beserta alasannya

Pada indikator mengenali data/konsep/prinsip yang termuat dalam informasi yang diberikan, berdasarkan deskripsi pada jawaban Subjek S2 pada Gambar 4., terlihat bahwa Subjek mengenali data/konsep/prinsip yang termuat dalam informasi yang diberikan. Subjek S2 dapat menuliskan anggota himpunan K dan L dengan tepat, ini menunjukkan bahwa Subjek S2 dapat mengenali hal-hal yang disajikan pada soal. Hal ini juga diperkuat dengan wawancara Subjek S2 berikut.

"Awalnya saya agak bingung dengan anggota bilangan $L$, karena di situ $x=5$ bilangan prima

pertama, kata-katanya agak membuat saya bingung Bu, kalo yang $\mathrm{K}$ kan sudah jelas ya $\mathrm{Bu}$.

$2<x<8$ di mana $x$ anggota bilangan asli."

Berdasarkan hasil wawancara tersebut, maka dapat diketahui bahwa Subjek S2 sudah mengenali data/konsep/prinsip yang termuat dalam informasi yang diberikan. Meskipun Subjek S2 mengaku agak kebingungan untuk menentukan anggota himpunan L. Oleh karena itu, peneliti menyimpulkan bahwa Subjek S2 mampu mengenali data/konsep/prinsip yang termuat dalam informasi yang diberikan dan memenuhi indikator 1 dari kemampuan pemahaman fungsional.

Selanjutnya indikator mengaitkan antara satu konsep/prinsip dengan konsep/prinsip yang lainnya dan serta menyatakannya dalam simbol matematika. Berdasarkan deskripsi pada jawaban Subjek S2 pada Gambar 4., terlihat bahwa Subjek S2 keliru dalam menafsirkan hal yang ditanyakan dalam soal, Subjek S2 tidak mengetahui maksud dari tanda kutip yang merupakan komplemen. Subjek S2 juga masih belum tepat dalam menafsirkan simbol irisan dan gabungan. Hal tersebut dapat terlihat dari jawaban Subjek S2 yang keliru dan tidak mengaitkan satu per satu konsepnya. Subjek langsung memberikan jawaban tanpa menuliskan konsep dan keterkaitannya terlebih dahulu. Berikut jawaban wawancara dengan Subjek S2.

"Saya tidak tahu Bu dengan maksud tanda kutip itu, hal pertama yang saya kerjakan yaitu dengan menuliskan anggota himpunannya terlebih dahulu, $K$-nya itu 3, 4, 5, 6, dan 7. L -nya itu 2, 3, 5, 7, dan 11. K ก L itu 3, 5, dan 7."

Berdasarkan hasil wawancara tersebut, maka dapat diketahui bahwa Subjek S2 tidak mengetahui bahwa tanda kutip tersebut merupakan komplemen, Subjek S2 bisa menyebutkan sampai ke tahap K $\cap \mathrm{L}$, akan tetapi tidak dapat mengaitkan antara satu konsep/prinsip dengan yang lainnya. Maka dapat disimpulkan bahwa Subjek S2 belum mampu mengaitkan antara satu konsep/prinsip dengan konsep/prinsip yang lainnya 
dan serta menyatakannya dalam simbol matematika, dan belum memenuhi indikator 2 dari kemampuan pemahaman fungsional.

Terakhir pada kemampuan fungsional adalah indikator menentukan solusi akhir beserta alasannya. Berdasarkan deskripsi pada jawaban Subjek S2 pada Gambar 4., Subjek S2 keliru dalam menentukan solusi akhir beserta alasannya, dikarenakan Subjek S2 tidak dapat menafsirkan tanda komplemen, masih keliru dalam menafsirkan simbol irisan dan gabungan, serta tidak dapat mengaitkan antara satu konsep/prinsip dengan yang lainnya. Berikut hasil wawancara dengan Subjek S1.

"Sebenernya saya bingung Bu menentukan komplemen itu karena sudah lupa. Saya menentukan solusi akhir seperti itu karena $K \cap$ L itu 3,5, dan 7. Komplemennya saya ambil angka 4 lalu digabung K jadi 3,4,5, dan 7."

Dari hasil wawancara tersebut, Subjek S2 keliru dalam menentukan solusi akhir beserta alasannya. Subjek S2 mengaku kebingungan untuk menentukan komplemennya, dengan alasan sudah lupa. Maka dapat disimpulkan bahwa Subjek S1 belum mampu menentukan solusi akhir beserta alasannya, dan belum memenuhi indikator 3 dari kemampuan pemahaman fungsional. Subjek S2 mengatakan bahwa soal pemahaman fungsional ini lebih sulit dari pada soal pemahaman komputasional.

\section{PEMBAHASAN}

Dari uraian hasil penelitian, dapat dilihat bahwa kedua subjek memenuhi hanya satu dari dua indikator soal pemahaman komputasional dan mememenuhi satu dari tiga indikator pemahaman fungsional. Subjek S1 dan Subjek S2 menyatakan bahwa soal pemahaman fungsional yang lebih sulit, hal ini sejalan dengan hasil penelitian yang telah dilakukan oleh Agustina, et.al. (2021), yang menyatakan bahwa kesulitan untuk menyelesaikan soal pemahaman konsep matematis dialami oleh mahasiswa pendidikan matematika pada indikator pemahaman fungsional dari pada indikator pemahaman komputasional.

Pada soal indikator pemahaman komputasional, Subjek S1 menguasai indikator 1 dari pemahaman komputasional yaitu mengidentifikasi data/konsep/prinsip yang terdapat dalam informasi yang diberikan, hal tersebut dapat dilihat dari jawaban subjek yang menuliskan informasi sesuai dengan apa yang diberikan di soal yaitu tentang jumlah keseluruhan siswa dalam satu kelas, jumlah siswa yang mengikuti kompetisi matematika, dan jumlah siswa yang mengikuti kompetisi IPA. Meskipun pada indikator ini Subjek S1 masih ada kekeliruan dalam menuliskan kompetisi IPA menjadi Fisika dan masih ada kekurangan penulisan informasi yang disajikan di soal yaitu jumlah siswa yang tidak mengikuti kedua kompetisi tersebut. Subjek juga dapat mengidentifikasi hal yang ditanyakan pada soal. Subjek 2 juga menguasai indikator 1 dari pemahaman komputasional yaitu mengidentifikasi data/konsep/prinsip yang terdapat dalam informasi yang diberikan, Subjek 2 mampu mengidentifikasi hal-hal yang terdapat dari soal yaitu tentang jumlah keseluruhan siswa dalam satu kelas, jumlah siswa yang mengikuti kompetisi matematika, dan jumlah siswa yang mengikuti kompetisi IPA. Subjek S2 menggambar diagram venn untuk mempermudah mengidentifikasi kelompok himpunan yang diketahui pada soal, meskipun masih ada kekurangan dalam penulisannya yaitu tidak adanya keterangan yang dipakai dalam diagram venn tersebut. Seperti penelitian yang telah dilakukan oleh Susiaty \& Haryadi (2019) bahwa Subjek yang memiliki kemampuan pemahaman matematis rendah melakukan banyak kekeliruan dalam menyelesaikan soal khususnya pada indikator pemahaman dalam mendefinisikan konsep secara tulisan, merepresentasikan suatu konsep dalam bentuk model, diagram dan simbol, mengidentifikasikan contoh dan bukan contoh suatu perbandingan serta mengubah suatu bentuk representasi ke bentuk lainnya.

Subjek S2 mengetahui apa maksud dari pertanyaan pada soal. Dari indikator pertama pemahaman komputasional tersebut dapat diketahui bahwa secara garis besar kedua Subjek memiliki kesamaan dalam 
mengidentifikasi data/konsep/prinsip yang terdapat dalam informasi yang diberikan, hal ini serupa dengan hasil dari penelitian yang telah dilakukan Nia, et.al. (2019), secara garis besar jawaban yang diberikan oleh kedua Subjek mempunyai persamaan pada cara penyelesaian soal pemahaman komputasional dan fungsional, hanya saja penggunaan metode yang kurang tepat.

Pada soal indikator pemahaman komputasional, Subjek S1 dan Subjek S2 belum memenuhi indikator melakukan perhitungan terhadap proses matematika dengan menyertakan aturan/prinsip/konsep yang digunakan pada setiap langkah pengerjaan yang merupakan indikator kedua dari pemahaman komputasional ini. Subjek S1 menyajikan ulang hitungan dengan menyertakan aturan/prinsip/konsep yang keliru dari jawaban sebenarnya. Subjek S1 langsung menjumlahkan kedua hal yang diketahui di soal tanpa menyertakan aturan/prinsip/konsep yang seharusnya. Subjek S1 juga menyadari bahwa seharusnya menggambar diagram venn himpunan terlebih dahulu agar dapat mempermudah perhitungan pada setiap langkah pengerjaan. Subjek S2 juga belum memenuhi indikator ini, pada tahap awal Subjek S2 menyajikan gambar diagram venn, tahap pengerjaan selanjutnya Subjek S2 mengurangi jumlah keseluruhan mahasiswa dengan jumlah mahasiswa yang tidak ikut kompetisi apapun untuk menemukan jumlah mahasiswa yang ikut kompetisi tersebut. Di tahap selanjutnya Subjek S2 keliru dalam menempatkan operasi penjumlahan dan pengurangan untuk mendapatkan jawaban yang ditanyakan yaitu jumlah mahasiswa yang mengikuti kompetisi keduanya. Tetapi Subjek S2 menyadari kekeliruannya dan menjelaskan posisi operasi penjumlahan dan pengurangan yang seharusnya.

Pada soal indikator pemahaman fungsional, Subjek S1 dan Subjek S2 memenuhi indikator pertama pemahaman fungsional yaitu mengenali data/konsep/prinsip yang termuat dalam informasi yang diberikan. Subjek S1 salah menafsirkan data/konsep/prinsip yang diketahui pada soal. Subjek S1 keliru dalam menuliskan anggota himpunan L yang hanya dituliskan satu anggota yaitu 5. Akan tetapi ketika wawancara Subjek S1 dapat mengenali anggota dari himpunan L tersebut, sehingga Subjek S1 memenuhi indikator pertama dari pemahaman fungsional tersebut. Subjek S2 dapat menuliskan anggota himpunan K dan L dengan tepat, ini menunjukkan bahwa Subjek S2 dapat mengenali hal-hal yang disajikan pada soal, meskipun pada hasil wawancara Subjek S2 mengakui kesulitan dalam menentukan anggota himpunan L. Hal ini dikarenakan Subjek belum mempunyai konsep materi bilangan yang merupakan materi pra syarat untuk materi himpunan, sejalan dengan penelitian yang dilakukan oleh Ratnasari \& Setiawan (2018) bahwa materi pra syarat pada himpunan yaitu konsep macam-macam bilangan seperti bilangan ganjil, bilangan asli, bilangan prima, bilangan genap, dan lain-lain tidak dikuasai oleh siswa.

Pada soal indikator pemahaman fungsional, Subjek S1 dan Subjek S2 belum memenuhi indikator kedua dari pemahaman fungsional yaitu mengaitkan antara satu konsep/prinsip dengan konsep/prinsip yang lainnya dan serta menyatakannya dalam simbol matematika. Subjek S1 keliru dalam menafsirkan hal yang ditanyakan dalam soal, Subjek S1 tidak mengetahui maksud dari tanda kutip yang merupakan komplemen. Subjek S1 juga keliru dalam menafsirkan simbol irisan dan gabungan. Hal tersebut dapat terlihat dari jawaban Subjek S1 yang keliru dan tidak mengaitkan satu per satu konsepnya. Subjek langsung memberikan jawaban tanpa menuliskan konsep dan keterkaitannya terlebih dahulu. Hal yang sama juga terjadi pada Subjek S2 yang keliru dalam mengartikan tanda kutip yang merupakan komplemen, keliru dalam menafsirkan simbol irisan dan gabungan, dan Subjek S2 juga tidak mengaitkan satu per satu konsep tersebut.

Subjek S1 dan Subjek S2 juga belum memenuhi indikator ketiga dari pemahaman fungsional yaitu menentukan solusi akhir beserta alasannya. Subjek S1 keliru dalam menentukan solusi akhir beserta alasannya, dikarenakan Subjek S1 keliru dalam menafsirkan tanda komplemen, keliru dalam menafsirkan simbol irisan dan gabungan, serta tidak dapat mengaitkan antara satu konsep/prinsip dengan yang lainnya. Subjek S2 juga mengalami hal serupa dengan Subjek S1, dikarenakan tidak memenuhi indikator kedua dari pemahaman fungsional maka Subjek S2 tidak memenuhi indikator ketiga dari pemahaman fungsional tersebut. 
Pada soal indikator kemampuan pemahaman komputasional dan fungsional ini, kedua subjek belum mendapatkan skor sempurna. Karena masing-masing subjek hanya memenuhi satu dari indikator masingmasing soal pemahaman tersebut. Seperti penelitian yang telah dilakukan oleh Hernaeny, et.al. (2021), dimana hasil penelitian tersebut menyatakan bahwa tidak ada skor sempurna yang didapat oleh kesembilan siswa yang melakukan tes kemampuan pemahaman komputasional dan fungsional yang diberikan, masingmasing siswa mempunyai keunggulan dan kekurangan pada setiap indikatornya.

Pemahaman konsep sangatlah penting, dikarenakan untuk melangkah ke kemampuan lain dibutuhkan suatu pemahaman konsep terlebih dahulu. Hal ini sesuai dengan penelitian yang dilakukan Kurniasi dan Juwita (2019) yang menyatakan bahwa apabila pemahaman konsep yang dimiliki mahasiswa baik, maka kemampuan lainnya akan mengiringi. Pada suatu pembuktian yang paling penting yaitu kemampuan pemahaman konsep, karena pada pemahaman konsep mahasiswa dituntut mengingat konsep terdahulu dan memahami setiap definisi, simbol, teorema, dan rumus yang berlaku.

\section{SIMPULAN}

Berdasarkan hasil dan pembahasan, menunjukkan bahwa kemampuan pemahaman matematis mahasiswa pada materi himpunan khususnya pada subjek yang memiliki kemampuan awal matematis kategori rendah, hanya mampu mengidentifikasi data dan informasi yang terdapat dalam informasi yang diberikan pada soal. Hal ini terungkap karena subjek hanya memenuhi masing-masing satu indikator pertama dari kemampuan pemahaman komputasional dan fungsional.

Penelitian ini masih perlu dikembangkan dan diperluas cakupannya. Peneliti belum dapat mengetahui secara mendalam kemampuan pemahaman komputasional dan fungsional pada dua kategori pemahaman lainnya yaitu tinggi dan sedang. Hal ini menarik untuk diteliti lebih lanjut bagi peneliti-peneliti lainnya, sehingga dapat diketahui kemampuan pemahaman matematis pada kategori tersebut.

\section{DAFTAR RUJUKAN}

Agustina, L., Rochmad, \& Isnarto. (2021). Kemampuan pemahaman konsep matematis pada mata kuliah pengantar dasar matematika. PRISMA: Proseding Seminar Nasional Matematika, 4, 262-267.

Asih, A., \& Imami, A. I. (2021). Analisis kemampuan pemahaman konsep matematis siswa SMP kelas VIII pada materi himpunan. Maju, 8(2), 9-16.

Aulia, A. A., Parta, I. N., \& Irawati, S. (2017). Pemahaman konsep fungsi invers siswa melalui pembelajaran kooperatif tipe Jigsaw. Jurnal Kajian Pembelajaran Matematika, 1(2), 106-112.

Ayuningrum, L., Kusuma, A. P., \& Rahmawati, N. K. (2019). Analisis kesulitan siswa dalam pemahaman belajar serta penyelesaian masalah ruang dimensi tiga. JKPM (Jurnal Kajian Pendidikan Matematika), 5(1), 135-142. https://doi.org/10.30998/jkpm.v5i1.5277

Davita, P. W. C., Nindiasari, H., \& Mutaqin, A. (2020). Pengaruh model problem based learning terhadap kemampuan pemahaman matematis ditinjau dari kemampuan awal matematis siswa. Tirtamath: Jurnal Penelitian Dan Pengajaran Matematika, $2(2), \quad 101-112$. https://doi.org/https://doi.org/10.48181/tirtamath.v2i2.8892

Dini, M., Wijaya, T. T., \& Sugandi, A. I. (2018). Pengaruh self confidence terhadap kemampuan pemahaman matematik siswa SMP. JURNAL SILOGISME: Kajian Ilmu Matematika Dan Pembelajarannya, 3(1), 1-7. https://doi.org/10.24269/js.v3i1.936

Fajar, A. P., Kodirun, K., Suhar, S., \& Arapu, L. (2018). Analisis kemampuan pemahaman konsep matematis siswa kelas VIII SMP Negeri 17 Kendari. Jurnal Pendidikan Matematika, 9(2), 229-239. 
https://doi.org/https://doi.org/10.36709/jpm.v9i2.5872

Farhan, M., \& Zulkarnain, I. (2019). Analisis kesalahan mahasiswa pada mata kuliah kalkulus peubah banyak berdasarkan Newmann's error analisis. JKPM (Jurnal Kajian Pendidikan Matematika), 4(2), 121-134. https://doi.org/https://doi.org/10.30998/jkpm.v4i2.3843

Ferdiana, V., \& Mulyatna, F. (2020). Pengaruh Model Pembelajaran Kooperatif Tipe Make a Match terhadap Pemahaman Konsep Matematika Siswa. Seminar Nasional Sains 2020, 1(1), 442-446. http://www.proceeding.unindra.ac.id/index.php/sinasis/article/view/4079

Hernaeny, U., Marliani, N., \& Marlina, L. (2021). Analisis kemampuan pemahaman konsep matematika pada materi bangun ruang sisi datar. Prosiding Seminar Nasional Penelitian Dan Pengabdian 2021, "Penelitian Dan Pengabdian Inovatif Pada Masa Pandemi Covid-19," 1(1), 604-611.

Hidayat, D. W., \& Pujiastuti, H. (2019). Analisis kesalahan siswa dalam menyelesaikan masalah matematis pada materi himpunan. Jurnal Analisa, 5(1), 59-67. https://doi.org/10.15575/ja.v5i1.4120

Jafar. (2013). Membangun pemahaman yang lengkap (Completely Understanding ) dalam pembelajaran konsep grup. KNPM V: Himpunan Matematika Indonesia, 87-95.

Kurniasi, E. R., \& Juwita, I. (2019). Analisis kemampuan pemahaman konsep matematis mahasiswa ditinjau dari kemampuan tinggi, sedang, rendah. Jurnal Ilmu Pendidikan Dan Kependidikan, 7(1), 21-34. https://doi.org/https://doi.org/10.35438/e.v7i1.160

Melawati, N. A. (2020). Analisis kemampuan komunikasi matematis ditinjau dari self efficacy siswa SMP/MTs pada materi bangun ruang sisi datar. In Skripsi. Universitas Islam Negeri Sultan Syarif Kasim Riau Pekanbaru.

Miles, M. B., \& Huberman, A. M. (1994). Qualitative Data Analysis. Sage Publications.

Nia, N. M., Darmawan, P., \& Prayekti, N. (2019). Kemampuan pemahaman matematis siswa SMP dalam menyelesaikan soal persamaan linier dua variabel ditinjau dari pemahaman matematis menurut Pollatsek. Prosiding Seminar Nasional MIPA UNIBA, 1(1), 45-78.

Ratnasari, S., \& Setiawan, W. (2018). Analisis kesulitan belajar siswa pada materi himpunan. Journal On Education, 01(02), 473-479.

Rosita, I., Hasanah, F. H., \& Wulansari, D. (2021). Analisis pemahaman fungsi invers pada guru matematika berdasarkan teori Skemp. Tirtamath: Jurnal Penelitian Dan Pengajaran Matematika, 3(1), 24-34. https://doi.org/https://doi.org/10.48181/tirtamath.v3i1.11173

Suarsana, I. M., Widiasih, N. P. S., \& Suparta, I. N. (2018). The effect of brain based learning on second grade junior students' mathematics conceptual understanding on polyhedron. Journal on Mathematics Education, 9(1), 145-155. https://doi.org/https://doi.org/10.22342/jme.9.1.5005.145-156

Sumarmo, U. (2010). Berfikir dan Disposisi Matematik: Apa, Mengapa, dan Bagaimana Dikembangkan Pada Peserta Didik. In FPMIPA UPI.

Suparni, E., Nurfitriyanti, M., \& Eva, L. M. (2021). Pengaruh resiliensi matematis terhadap kemampuan komunikasi matematis. JKPM (Jurnal Kajian Pendidikan Matematika), 6(2), 157-166. https://doi.org/https://doi.org/10.30998/jkpm.v6i2.9179

Susiaty, U. D., \& Haryadi, R. (2019). Analisis kemampuan pemahaman matematis siswa dalam menyelesaikan soal perbandingan di kelas VII SMP. Jurnal Pendidikan Informatika Dan Sains, 8(2), 239-248. https://doi.org/10.31571/saintek.v8i2.1574

Yanti, R., Laswadi, Ningsih, F., Putra, A., \& Ulandari, N. (2019). Penerapan Pendekatan Saintifik Berbantuan Geogebra dalam Upaya Meningkatkan Pemahaman Konsep Matematis Siswa. AKSIOMA: Jurnal Matematika Dan Pendidikan Matematika, 10(2), 180-194. https://doi.org/https://doi.org/10.26877/aks.v10i2.4399 